\title{
Recorregut de recerca geològica i mineralògica per les comarques del Pallars Jussà, de la Noguera i de I'Alt Urgell: des d'Isona al Port de Comiols, Peramola i a Oliana
}

Josep Maria Mata-Perelló

Joaquim Sanz Balagué

\section{XARAGALL \\ REVISTA DE CIÈNCIES DE LA CATALUNYA CENTRAL}

ก. 9

SETEMBRE 2015 


\title{
RECORREGUT DE RECERCA GEOLÒGICA I MINERALÒGICA PER LES COMARQUES DEL PALLARS JUSSÀ, DE LA NOGUERA I DE L'ALT URGELL: DES D'ISONA AL PORT DE COMIOLS, PERAMOLA I A OLIANA
}

\author{
Josep Maria Mata-Perelló \\ Museu de geologia Valentí Masachs, Escola Politècnica Superior d'Enginyeria de Manresa \\ (EPSEM), Universitat Politècnica de Catalunya · BarcelonaTech (UPC), 08272 Manresa, Spain
}

\section{Joaquim Sanz Balagué}

Departament d'Enginyeria Minera i Recursos Naturals (EMRN), Escola Politècnica Superior d'Enginyeria de Manresa (EPSEM), Universitat Politècnica de Catalunya . BarcelonaTech (UPC), 08272 Manresa, Spain

Paraules clau: Sistema Pirinenc, Patrimoni miner

\section{Resum}

Itinerari realitzat l'11 d'agost de 2014. En aquesta ocasió, el recorregut de l'itinerari discorrerà, en la seva quasi totalitat pel Sistema Pirinenc, i més concretament ho farà per la seva Unitat Sudpirinenca Central (també anomenada com a les Serres Exteriors Prepirinenques).

En concret, el recorregut del present itinerari passarà per dos dels seus sectors més representatius; concretament pel Mantell del Montsec, el qual es recorrerà d'Oest a Est, al llarg de tot l'itinerari. Així, al llarg de l'itinerari, anirem trobant afloraments dels materials mesozoics que constitueixen aquest mantell (del Juràssic i del Cretàcic, fonamentalment, pels indrets per on transcorre); i també dels terrenys cenozoics que també el constitueixen (del Paleocè i de I'Eocè Inferior). Tanmateix, també trobarem afloraments dels conglomerats oligocènics postorogènics, els quals cobreixen sovint als anteriors; el mateix que els terrenys cenozoics més recents del Pleistocè i de l'Holocè, igualment detrítics.

Per d'altra banda, el recorregut de l'itinerari discorrerà per tres de les comarques pirinenques de les Terres de Lleida; concretament per la del Pallars Jussà (per on començarà a Isona) i per la de I'Alt Urgell (per on finalitzarà a Oliana). Tanmateix es farà un curt recorregut per la comarca de la Noguera; concretament pel terme de la Baronia de Rialb, cap a la part central del recorregut de l'itinerari. 


\section{Objectius fonamentals}

Es centraran en els aspectes geològics, geomorfològics $\mathrm{i}$ mineralògics que apuntarem a continuació:

1.- Estudi de l'estructura materials dels relleus prepirinencs de la Unitat Sud-pirinenca Central, que es tallaran al llarg del recorregut de tot l'itinerari, entre la Pobla de Segur i Isona. Aquests relleus, es situaran en la seva major part dintre del Mantell de Montsec.

2.- Estudi i observació dels materials mesozoics (del Juràssic i sobretot del Cretàcic), i del cenozoic (fonamentalment de l'Eocè i de l'Oligocè), que formen part dels relleus dels mantells acabats d'esmentar al paràgraf anterior. I, tanmateix dels materials oligocènics postorogènics que ocasionalment els cobreixen.

3.- Observació a distancia del Mantell de Bóixols, que no arribarem a tallar. I també del Diapir de Montmagastre, que tampoc tallarem en aquest recorregut.

4.- Reconeixement de diverses mineralitzacions situades al llarg del recorregut del present itinerari, com les següents, d'acord amb el sentit de la marxa, tot i que en general seran poc importants.

5.- Observació dels diferents indrets relacionats amb el patrimoni geològic que anirem trobant al llarg del recorregut d'aquest itinerari.

6.- Observació dels diferents indrets relacionats amb el patrimoni miner, si s'escau, que anem trobant al llarg del recorregut d'aquest itinerari.

\section{Antecedents}

En relació amb aquest itinerari geològico-mineralògic, no existeix cap altre itinerari coincident. Això si, hi ha antecedents parcials marginals, pel que fa al primer tram del recorregut; concretament: de MATA-PERELLÓ (2002a, 2002b, 2009 i 2013); així com de MATAPERELLÓ i MONTANÉ (2005 i 2006) i MATA - PERELLÓ i SANZ BALAGUÉ (2014). Pel que fa a la part final, hi ha un altres antecedents nostre: MATA - PERELLÓ (2005 i 2006).

Pel que fa a les mineralitzacions que veurem en aquest itinerari, cal dir que també ja estat prèviament descrites per nosaltres mateixos en MATA-PERELLÓ (1991). En aquest treball es fa referència a les mineralitzacions catalanes en general, parlant-se també de les situades al llarg d'aquest itinerari; i que es distribueixen tant per la Noguera, com pel Pallars Jussà.

I pel que fa a l'estructura geològica, ens remetérem a RIBA et altri (1976), i a GUIMERÀ et altri (1992). En ambdós treballs, es fa referència a l'estructura geològica dels Països Catalans. Per d'altra banda, també ens cal fer referència de ROSELL (1970); així com de l'IGME (1994).

Finalment, cal dir que tots aquests treballs, es trobaran relacionats, per estricte ordre alfabètic, dintre de l'apartat dedicat a les REFERĖNCIES BIBLIOGRÀFIQUES, al qual es remetem, pel que s'escaigui. 


\section{Recorregut de l'itinerari}

Aquest itinerari, s'iniciarà a la població de Isona,, per on es farà la primera aturada, tot seguint la carretera de doble denominació C - 363 / L - 511 (la qual es dirigeix cap a Coll de Nargó). Després de retornar a Isona, el recorregut continuarà cap a llevant, seguint la carretera comarcal $C-1412 b$ (que també és la $C-74$ ). Seguint per aquesta carretera es farà una aturada prop de Llordà.

Després, el recorregut continuarà amunt, per l'esmentada carretera. Així es passarà per Biscarri i més endavant per Benavent de la Conca, per on es farà una nova aturada. Seguidament, el recorregut arribarà al Port de Comiols, per on s'abandonarà la comarca del Pallars Jussà, entrant a la de la Noguera. Prop del port, de baixada es farà una altra aturada.

Més endavant, en arribar a Folquer, es deixarà per la dreta la carretera d'Artesa de Segre (la $\mathrm{L}$ - 512, que també és la C - 74). Així, caldrà seguir cap a Ponts, per la carretera $C$ - 1214b, que ara és també la $C-361$. Seguint per aquesta carretera, en arribar al Palau de Rialb, es trobarà una carretereta que es dirigeix cap a Pallerols $i$ despès cap a Sant Marc, Seguint per aquest vial, aviat deixarem la Noguera i entrarem a I'Alt Urgell, a Peramola. En aquest tram, caldrà fer diverses aturades.

I, finalment, des de Peramola, el recorregut es dirigirà cap a Tragó i finalment cap a Oliana, per on finalitzarà el recorregut d'aquest itinerari.

\section{Advertiments previs}

Com en altres recorreguts de RECERCA GEOLÒGICA I MINERALÒGICA ..., si es disposa del temps suficient, poden efectuar-se passant per totes les parades i filloles. En cas contrari, recomanem prescindir de les anomenades PARADES - CONDICIONALS.

Per d'altra banda, cal tenir cura del coneixement de l'estat de conservació d'alguns dels trams dels camins a recórrer. En concret, el d'aproximació a les mines de bauxita de Peramola, prop de Sant Marc.

Per d'altra banda, i a l'igual que en altres recorreguts semblants, recomanem tenir el màxim de cura i de respecte, entorn de la Natura que ens rodeja. 


\section{Descripció de l'itinerari}

Com ja és habitual, farem una sèrie de PARADES (o de ESTACIONS). En cada una d'elles, farem esment del terme municipal on es troben (en el cas de que no quedi clar, al situar la parada), així com del número del MAPA TOPOGRÁFICO NACIONAL (a escala 1:50.000), que indicarem entre parèntesi.

Per d'altra banda, en cada una de les parades indicarem el nom del municipi, en el qual es troben situades. També indicarem el nombre de la comarca en el qual es troba situada. En aquesta ocasió, utilitzarem els dos següents fulls: 290 (Isona), 291 (o d'Oliana), 328 (Artesa de Segre) i 329 (o de Ponts). Tots aquests fulls, han estat publicats per Instituto Geogràfico y Catastral de España.

Així doncs, la relació general ordenada de les aturades que composen aquest itinerari, es el següent:

\subsection{Parada 1 - CONDICIONAL.PARC CRETÀCIC DE LA POSA. (Santuari de la Mare de Deu de la Posa, terme municipal d'Isona i la Conca Dellà, comarca del Pallars Jussà). (Full 290).}

Tot i que el recorregut l'haurem començat a la població d'Isona, ens haurem desplaçat cap a llevant, tot fent una fillola. Així, haurem agafat la carretera $L$ - 511 (que també és la C - 363). En agafar-la, haurem anat cap el Santuari de la Posa. Així arribarem primer a la cruïlla d'Abella de la Conca. Molt poc abans trobarem un camí que es dirigeix cap aquest santuari. Aquí farem la primera parada, a uns $3 \mathrm{Km}$ d'Isona.

En aquest recorregut, haurem anat trobant els afloraments dels materials cretàcics, que formen part dels sectors més septentrionals del Mantell del Montsec. Així, haurem vist afloraments eminentment carbonatats i calcolutítics del Cretàcic Superior, fonamentalment del Garumnià, en arribar a l'indret de la present aturada.

En aquest lloc es troba un interessant jaciment d'icnites (de petjades), que inicialment es van atribuir a dinosaures. Posteriorment, s'ha vist que son icnites de rajades. Tot i això, constitueix un altre indret del interessant del nostre Patrimoni Geològic, al marge de les darreres polèmiques sobre la seva autenticitat. A l'actualitat, en aquest indret s'ha situat el Parc Cretàcic de la Posa. Així, per part del Museu d'Isona, s'ha preparat l'indret per a les visites i es poden observar centenars d'icnites de les esmentades rajades. Aquestes es troben per sota de l'ermita, en una vessant de la Colomera.

Per d'altra banda, en aquest indret es poden veure nivellets de lignits, que temps enllà es van intentar d'explotar. Aquests lignits formen part de la Conca Lignitífera d'Isona. Els lignits es situen sobre els afloraments del Garumnià. FOTOGRAFIA 1 


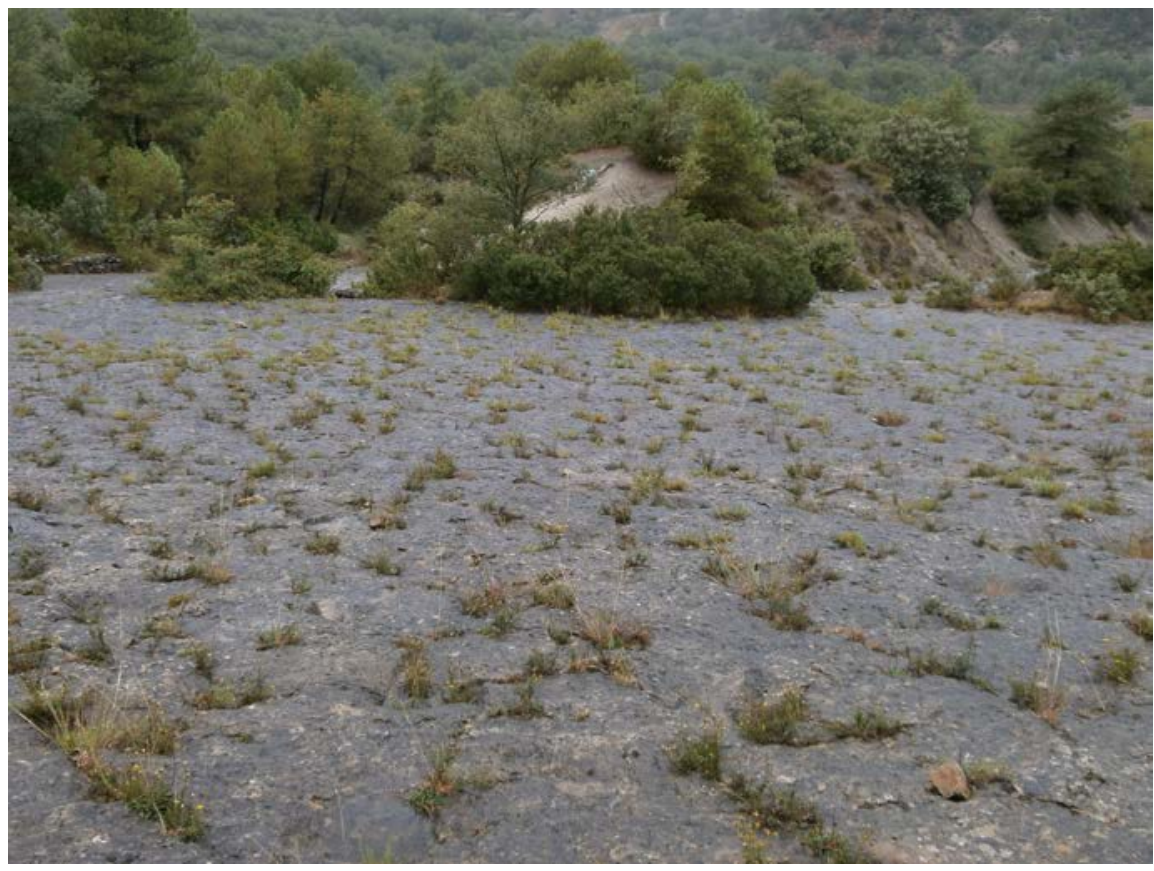

FOTOGRAFIA 1. PARADA 1

Un aspecte de les icnites del Parc Cretàcic Isona

\subsection{Parada 2. IMMEDIACIONS DEL Km 38, CARRETERA C - 1214b. (Llordà, terme municipal d'Isona i la Conca Dellà, comarca del Pallars Jussà). (Full 290).}

Després de realitzar la parada anterior, ens caldrà anar cap a la població d'Isona, ens Així, haurem agafat la carretera L - 511 (que també es denomina C - 363). Més tard. En arribar a aquesta darrera població, ens caldrà arribar a la carretera C - 1412 (o C - 74). En agafar-la ens caldrà anar cap a llevant, per tal d'arribar a les immediacions del Km 38. Per on farem una aturada, a uns $7 \mathrm{Km}$ de la parada anterior.

En aquest recorregut, hem anat trobant afloraments dels materials cretàcics, que formen part del Mantell del Montsec; així, haurem trobat nivells de calcolutites, generalment grises, les quals formen part del Garumnià; del trànsit del Cretàcic al Paleocè; tot i que per aquests indrets, aquests materials són del Cretàcic.

Entre aquests nivells, a l'indret de la parada, es fan clarament palesos uns nivellets de lignits. FOTOGRAFIA 2 


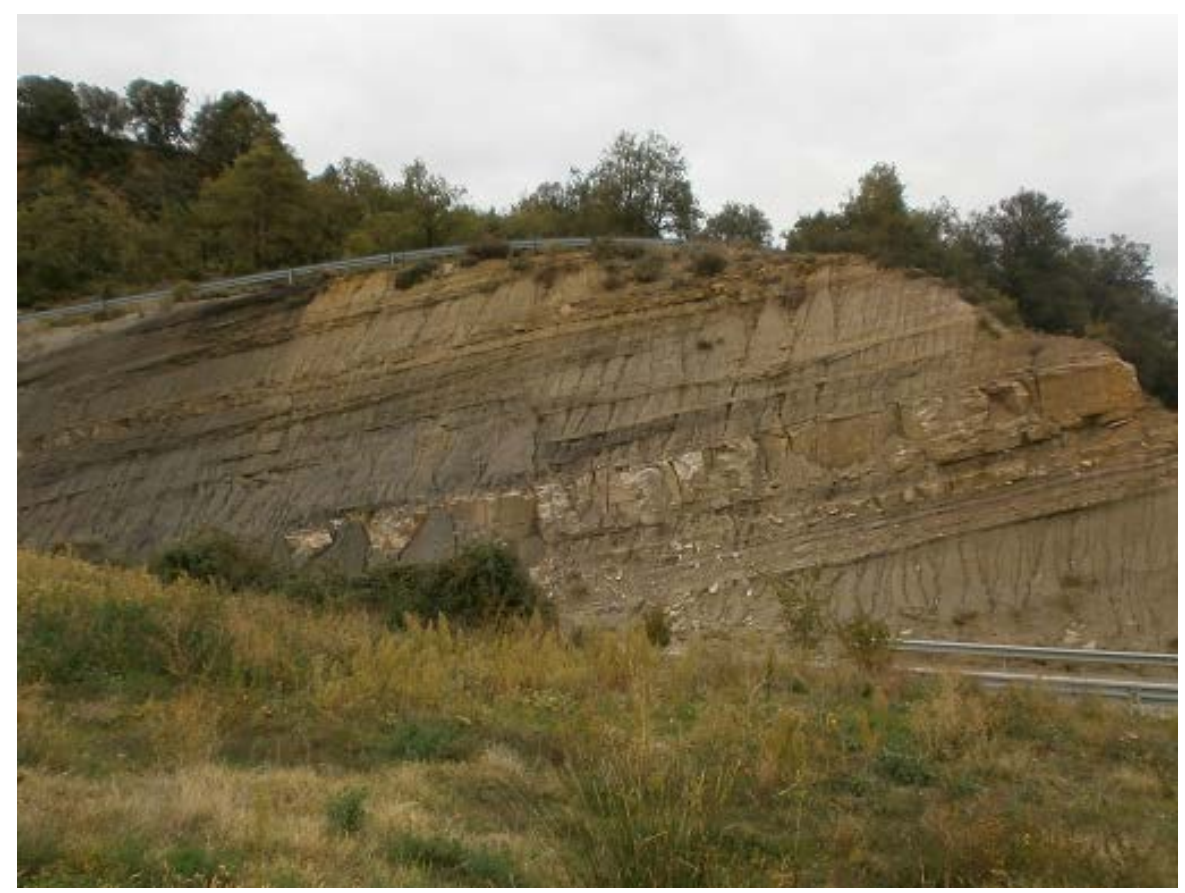

FOTOGRAFIA 2. PARADA 2

Aflorament de lignits a la carretera $C-1412 b$, prop de Llordà

\subsection{Parada 3. TERRERS DEL PORT DE COMIOLS, CARRETERA C - 1214b. (Benavent de la Conca, terme municipal d'Isona i la Conca Dellà, comarca del Pallars Jussà). (Full 290).}

Després de fer l'aturada anterior, cal fer un nou recorregut, seguint sempre la carretera C 1412b, anant cap a llevant. Així, aviat passarem per les immediacions de Biscarri i poc després arribarem a Benavent de la Conca. En arribar-hi, podem fer una nova aturada, a uns $8 \mathrm{Km}$ de l'anteriorment realitzada.

En aquest recorregut, haurem anat trobant afloraments dels materials mesozoics, generalment del Garumnià; dels materials del trànsit del Cretàcic al Paleocè. Així, haurem trobat nivells de gresos i de calcolutites. Tanmateix, a $1 \mathrm{Km}$ de la parada anterior, prop d'una corba, haurem tornat a trobar uns nivellets de lignits, intercalats entre nivells de calcolutites.

Més endavant, per sobre dels materials anteriors, es fan ben palesos uns nivells de conglomerats postorogènics. Aquets materials es fan molt evidents a Benavent de la Conca. FOTOGRAFIA 3. 


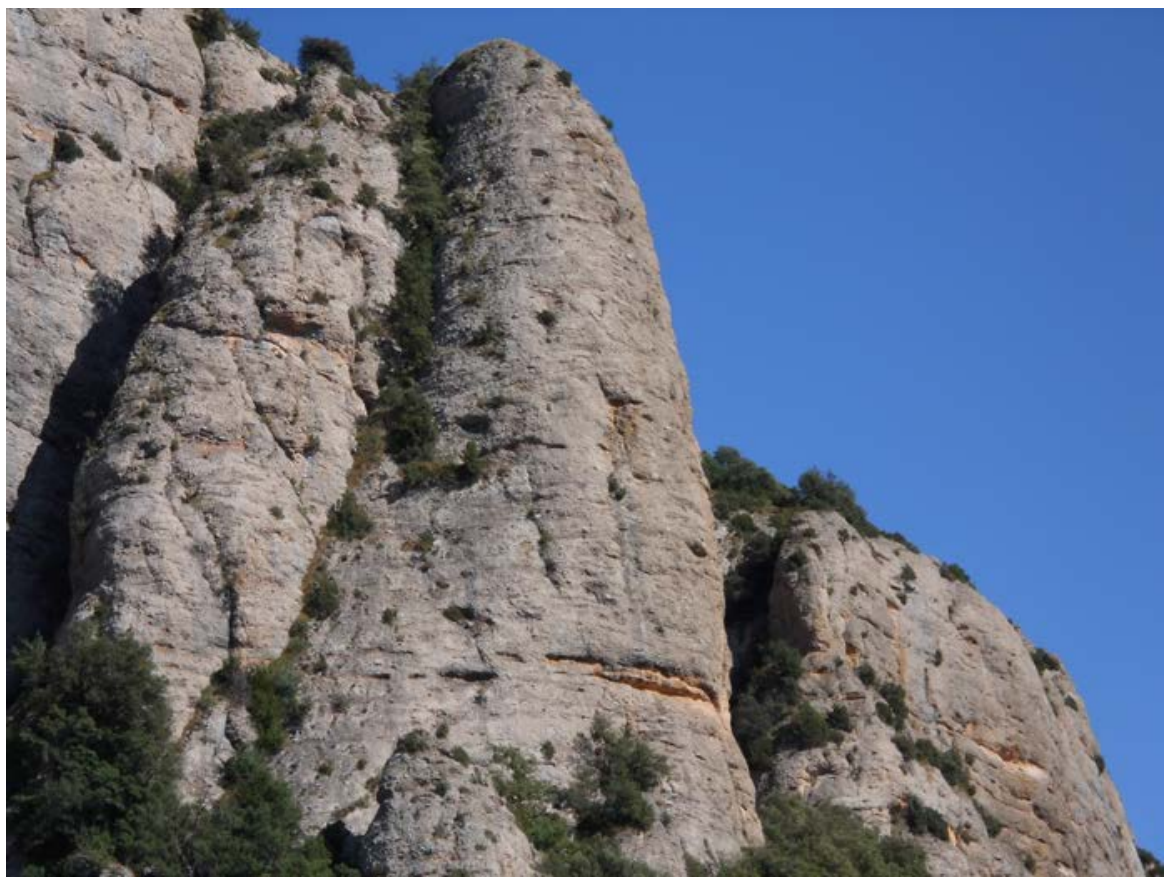

FOTOGRAFIA 2. PARADA 3

Un aspecte dels conglomerats postorogènics de Benavent de la Conca

Una mica més endavant, en sobrepassar Benavent de la Conca, es fan paleses unes explotacions de materials detrítics, de derrubis de pendent,. FOTOGRAFIA 4,

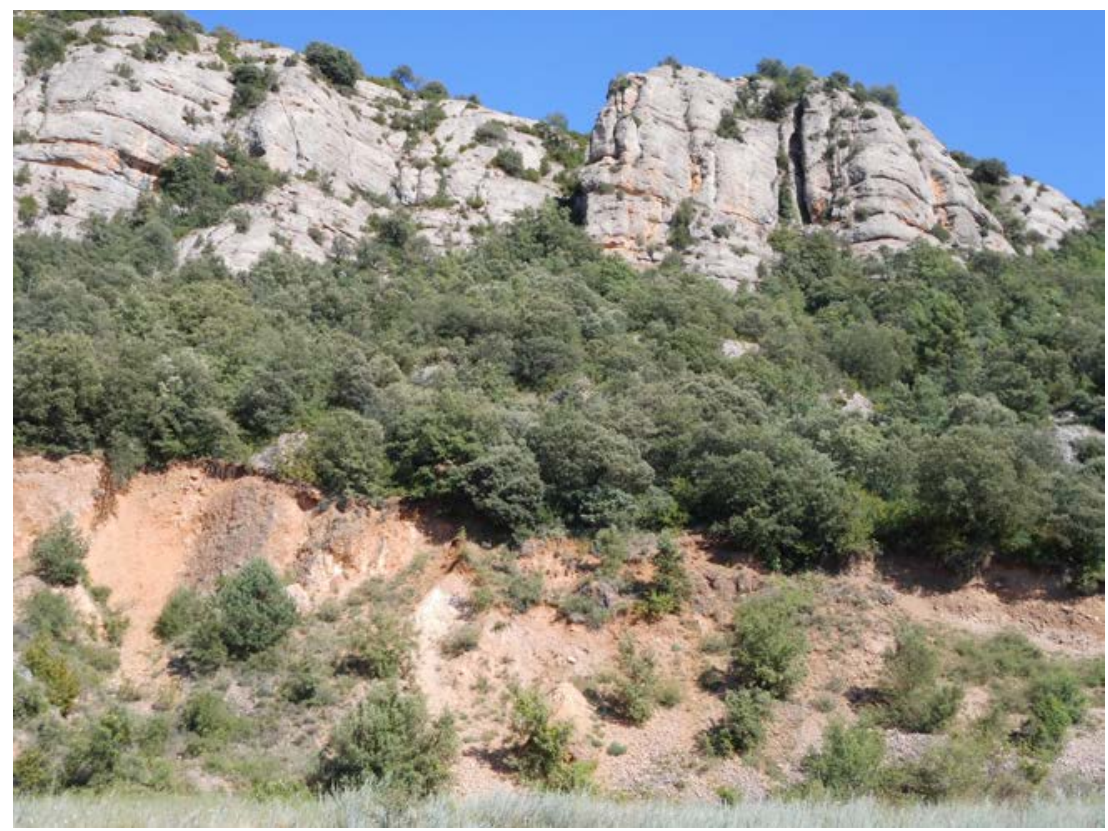

FOTOGRAFIA 4. PARADA 3

Explotació de derrubis de pendent. Immediacions de Benavent de la Conca. Terrers 


\subsection{Parada 4 - CONDICIONAL. BAIXADA DEL PORT DE COMIOLS, CARRETERA C - 1214b. (Comiols, terme municipal d'Artesa de Segre, comarca de la Noguera). (Full 290).}

Després de realitzar la parada anterior, cal continuar cap el Port de Comiols, pujant per la carretera $C$ - 1412b (C - 74). Més endavant, en sobrepassar el port, ens convindrà baixar cap a Ponts i cap Artesa de Segre. Així, haurem passat de la comarca del Pallars Jussà a la de la Noguera. En aquest descens, a uns $3 \mathrm{Km}$ del port i a uns $5 \mathrm{Km}$ de la parada anterior, en podem realitzar una altra.

En aquest recorregut, en arribar al port, haurem trobat els materials detrítics esmentats a l'aturada anterior. Més endavant, per sota d'aquests, haurem trobat uns nivells de calcolutites i de gresos ocres els quals pertanyen a la Unitat de Comiols, de l'Oligocè. Aquets són els materials que apareixen a l'indret de l'aturada. Aquests materials fossilitzen els materials cretàcics del Mantell del Montsec.

Per d'altra banda, en aquest descens es va veient molt clar el mal anomenat "diapir de Montmagastre" el qual es troba situat al Sud d'on ara som. FOTOGRAFIA 5.

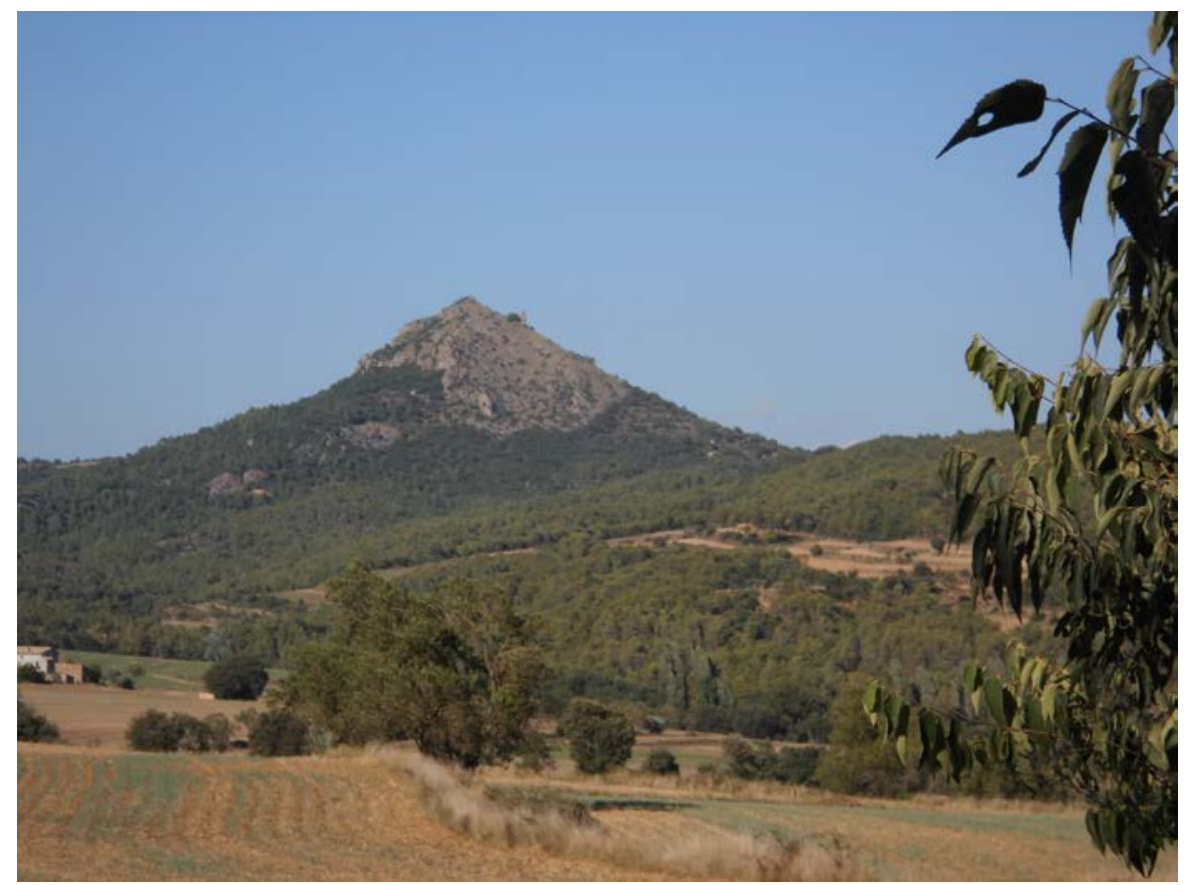

FOTOGRAFIA 5. PARADA 4

Un aspecte del mal anomenat Diapir de Montmagastre. En realitat es un encavalcament dels materials triàsics sobre els Cretàcic. Ve a ésser una continuació cap a llevant de l'encavalcament del Montsec, en bona part fossilitzat pels materials detrítics dels nivells de Comiols.

La fotografia està presa des del Sud de Montmagastre. 


\subsection{Parada 5. TRENCALL DE SANT CRISTÒFOL, CARRETERA C-1412b, (la Serra, terme de la Baronia de Rialb, comarca de la Noguera). (Full 291).}

Després d'efectuar l'aturada anterior, cal seguir per la carretera C-1212b (C - 74), tot baixant cap a Folquer. A partir d'aquest indret, caldrà seguir cap al SE, per la carretera que es dirigeix cap a Ponts, la mateixa C -1412b (essent ara la C - 361), deixant per la dreta la carretera que es dirigeix cap Artesa de Segre (la $L-512$ / C - 74). A partir d'aquest indret, ens caldrà seguir cap a Ponts. Així, es passarà per les immediacions del Palau de Rialb. Poc després trobarem el trencall (per l'esquerra) de la carretera que es dirigeix cap Sant Cristòfol i Gavarra. A poca distancia d'aquest trencall, baixant cap a Ponts, caldrà fer la una nova aturada, després d'haver recorregut uns $10 \mathrm{Km}$, des de la parada anteriorment realitzada. Aquesta aturada la farem prop del $\mathrm{Km} 15^{\prime} 5$ de la carretera.

En aquest recorregut hem anat trobant els materials oligocènics (amb gresos i calcolutites ocres), els quals cobreixen en molt bona part als materials mesozoics del Mantell de les Serres Marginals. Aquests materials son els que hem vist anteriorment, els anomenats Nivells de Comiols. Aquests materials apareixen aquí, en aquest indret, fracturats, tot formant una falla inversa, molt patent. Aquesta falla pirinenca, forma part de l'estructura de Montmagastre, el qual es troba al WSW d'on ara ens trobem situats. Aquesta estructura es fa clarament palesa des de l'indret on ara ens trobem. FOTOGRAFIA 6.

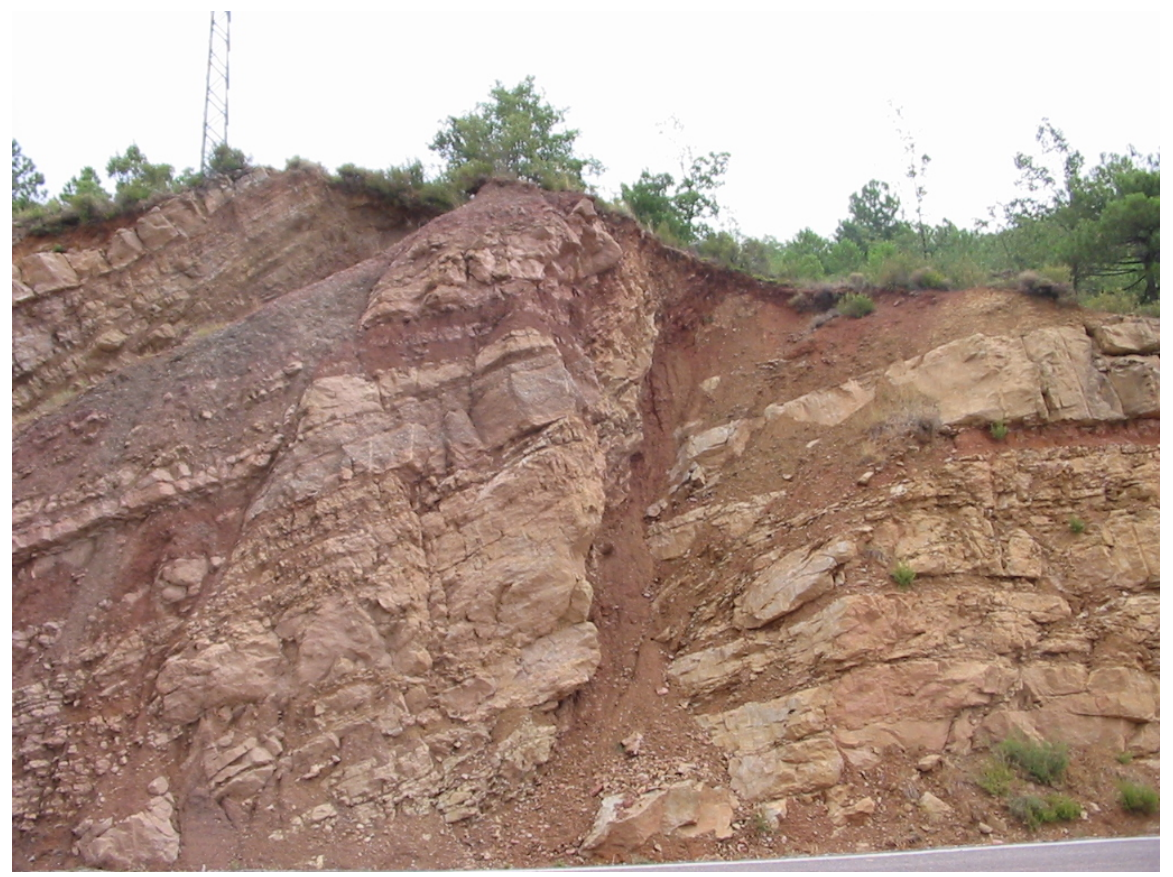

FOTOGRAFIA 6. PARADA 5

Falla inversa de Bellfort. Carretera C - 1412b. Km 15'5 


\subsection{Parada 6 - CONDICIONAL. TRENCALL DE BELLFORT, CARRETERA C - 1412b, IMMEDIACIONS DEL Km 13. (Bellfort, terme de la Baronia de Rialb, comarca de la Noguera). (Full 291).}

Després de fer l'aturada anterior, cal iniciar una fillola, anant cap al S i SE, per la carretera C 1412b (C - 361). En arribar a les immediacions del trencall de Bellfort, podem fer una nova aturada, aproximadament a uns $2^{\prime} 5 \mathrm{Km}$ de la parada anteriorment realitzada.

En aquest recorregut, hem anat trobant els materials oligocènics esmentats a l'aturada anterior. Aquests, són també els materials que apareixen a l'indret de l'aturada.

Des d'aquest indret, mirant cap a ponent, es pot gaudir d'una bona observació de l'estructura de Montmagastre, que hem vist a la PARADA 4. Tot i així, ara l'estem veient des de posicions més orientals. FOTOGRAFIA 7.

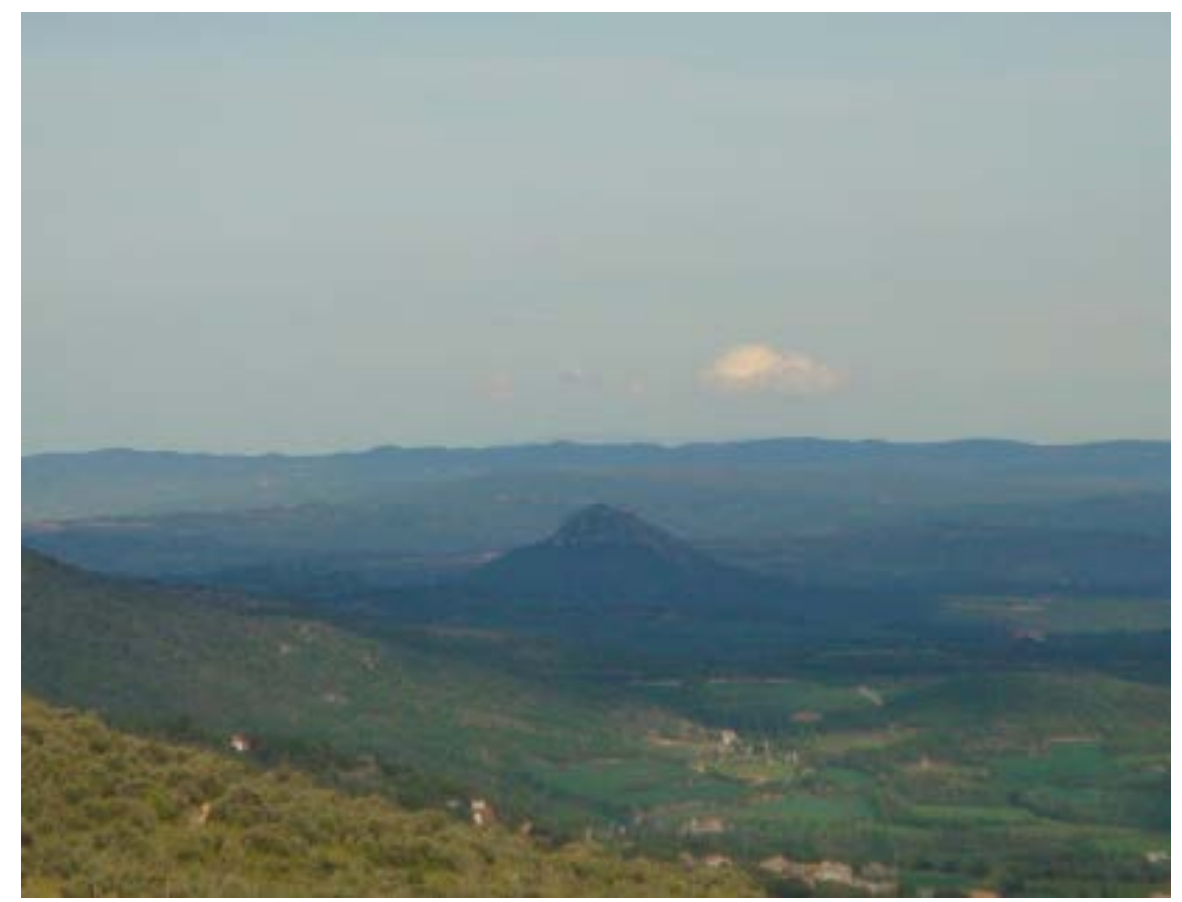

FOTOGRAFIA 7 PARADA 6

Un aspecte del mal anomenat Diapir de Montmagastre. En realitat es un encavalcament dels materials triàsics sobre els Cretàcic. Ve a ésser una continuació cap a llevant de l'encavalcament del Montsec, en bona part fossilitzat pels materials detrítics dels nivells de Comiols.

La fotografia està presa des de posicions orientals, prop de Bellfort 


\subsection{Parada 7. MINES DE SANT MARC, (termes de la Baronia de Rialb i de Peramola, comarques de la Noguera i de l'Alt Urgell). (Full 291).}

Després de fer l'aturada anterior, cal retornar enrere, per tal de continuar per la carretereta que es dirigeix cap a Sant Cristòfol. Més endavant trobarem un altre trencall (ara de terra, i per l'esquerra) el qual es dirigeix cap a Pallerols i cap a Sant Marc. Ens caldrà agafar-ho, i ens durà cap a les antigues Mines de Sant Marc, per on farem una nova aturada, després de recórrer uns 12-15 Km, des de la parada anteriorment.

En aquest recorregut hem anat trobant inicialment els materials esmentats a la parada anterior. Tot això fins prop de Pallerols. Després, haurem començat a trobar els materials mesozoics, fonamentalment de caràcter carbonatat. Aquests materials pertanyen en bona part al Cretàcic $i$ es troben situats dintre del Mantell de les Serres Marginals. Per d'altra banda, en tot aquest recorregut, mirant cap a ponent, es fa clarament palesa l'imponent estructura de Montmagastre,

Per d'altra banda, en aquest lloc hi ha unes interessants mineralitzacions bauxitíferes de rebliment de cavitats d'origen kàrstic. Aquestes cavitats es troben situades entre uns afloraments de les roques carbonatades del Juràssic. Les mineralitzacions consisteixen en concentracions de BAUXITA, una roca amb presència de diversos minerals d'alumini com els següents: BOEHMITA, DIASPOR i HIDRALGIRITA. També hi es present la CAOLINITA. Conjuntament, amb els anteriors, cal fer esment de diversos minerals de $\mathrm{Fe}$, com és el cas de I'HEMATITES (és, precisament, el responsable del color rogenc de les bauxites). FOTOGRAFIES 8 i 9.

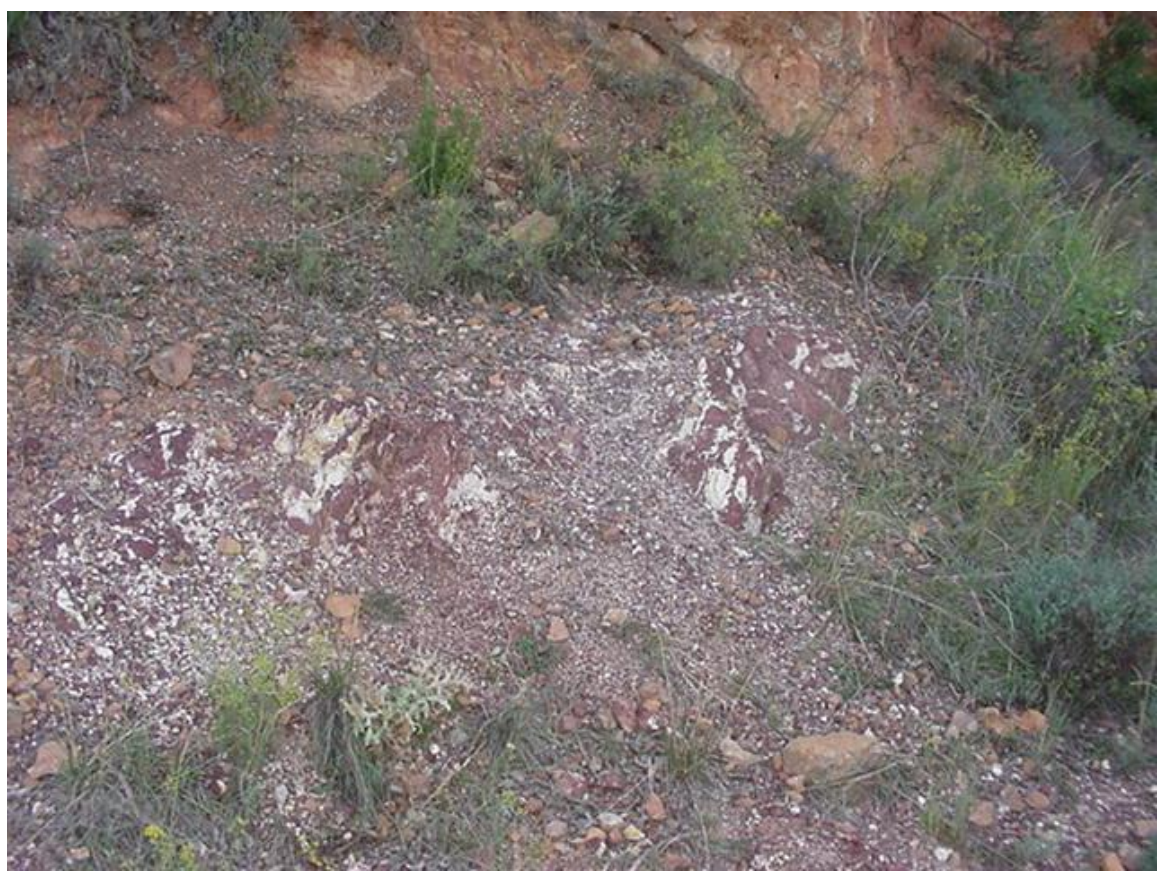

FOTOGRAFIA 8. PARADA 7

Aflorament de les bauxites a Sant Marc 


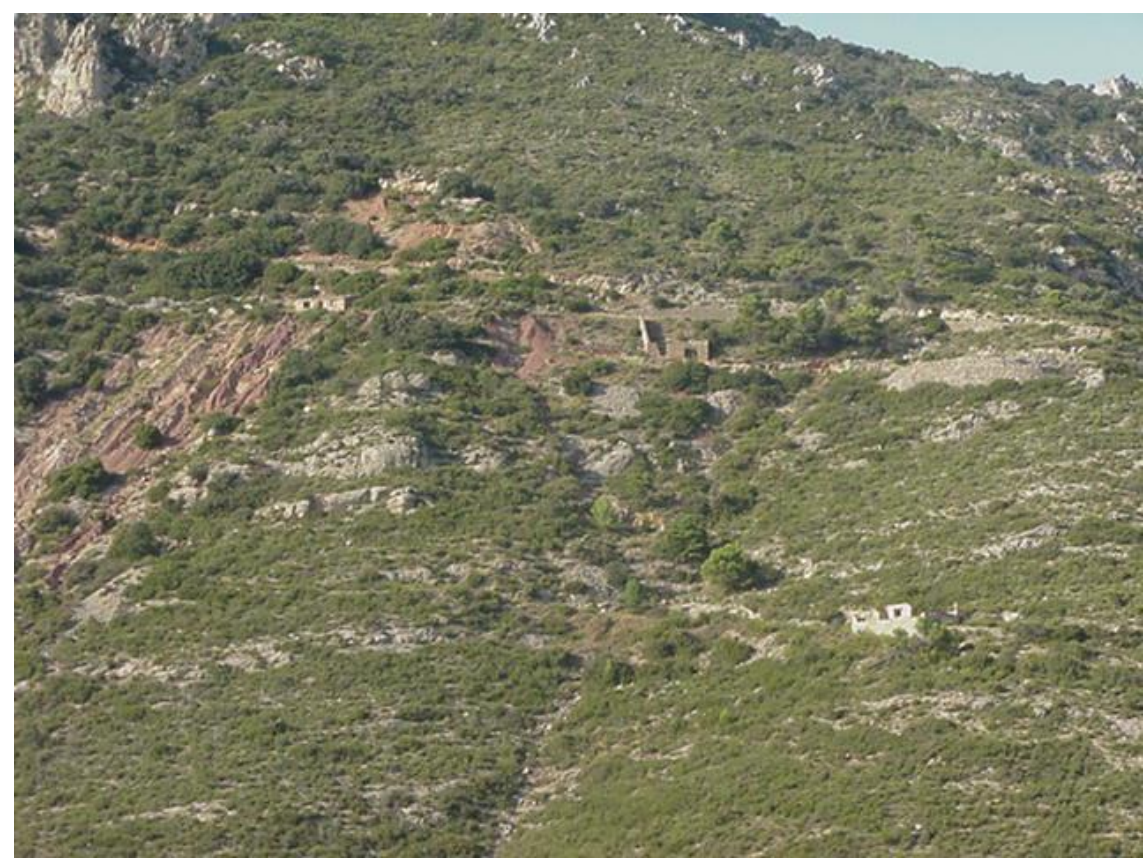

FOTOGRAFIA 9. PARADA 7

Aspecte general de les explotacions al terme de Peramola

Cal dir, finalment, que durant la primera midat d'aquest segle, es van realitzar diverses tasques de reconeixement d'aquests indicis, per tal d'intentar aprofitar les bauxites, com a mena de I’Alumini.

\subsection{Parada 8. TERRERS DE PERAMOLA, (terme municipal de Peramola, comarca de l'Alt Urgell). (Full 291).}

En cas d'haver fet la parada anterior, cl tornar enrere, cap a la carretera, que ens aproparà cap a Peramola. En passar per sota de l'Ermita de Sant Marc, es troba a la bora de la carretera una gran explotació de terres, per on farem aquesta nova aturada, a uns $4 \mathrm{Km}$ de l'anterior.

En aquest lloc s'han explotat els derrubis de pendent procedents de la Serra de Sant Marc i també de la Serra de Turb. que tenim per sobre. Aquests materials molt heteromètrics $\mathrm{i}$ eminentment carbonatats, s'han emprat com a àrids naturals per a la construcció de la carretera. Aquest indret també es troba sota de Encavalcament principal sud-pirinenc.

Per d'altra banda, des d'aquest indret, mirant cap al Nord, es poden veure algunes de les antigues explotacions de bauxita (situades entre Sant Marc i Peramola). Aquestes són de característiques similars a les de la parada anterior, amb les quals formen part dels anomenats jaciments bauxitifers de la Serra de Turb.

Per d'altra banda, mirant cap a llevant, es pot gaudir d'una bona observació de l'Anticlinal d'Oliana. Aquest es localitza sobre materials cenozoics, els quals es troben encavalcats per els materials cretàcics de l'extrem oriental del Mantell del Montsec, dintre de la Serra de Turb. FOTOGRAFIA 10 


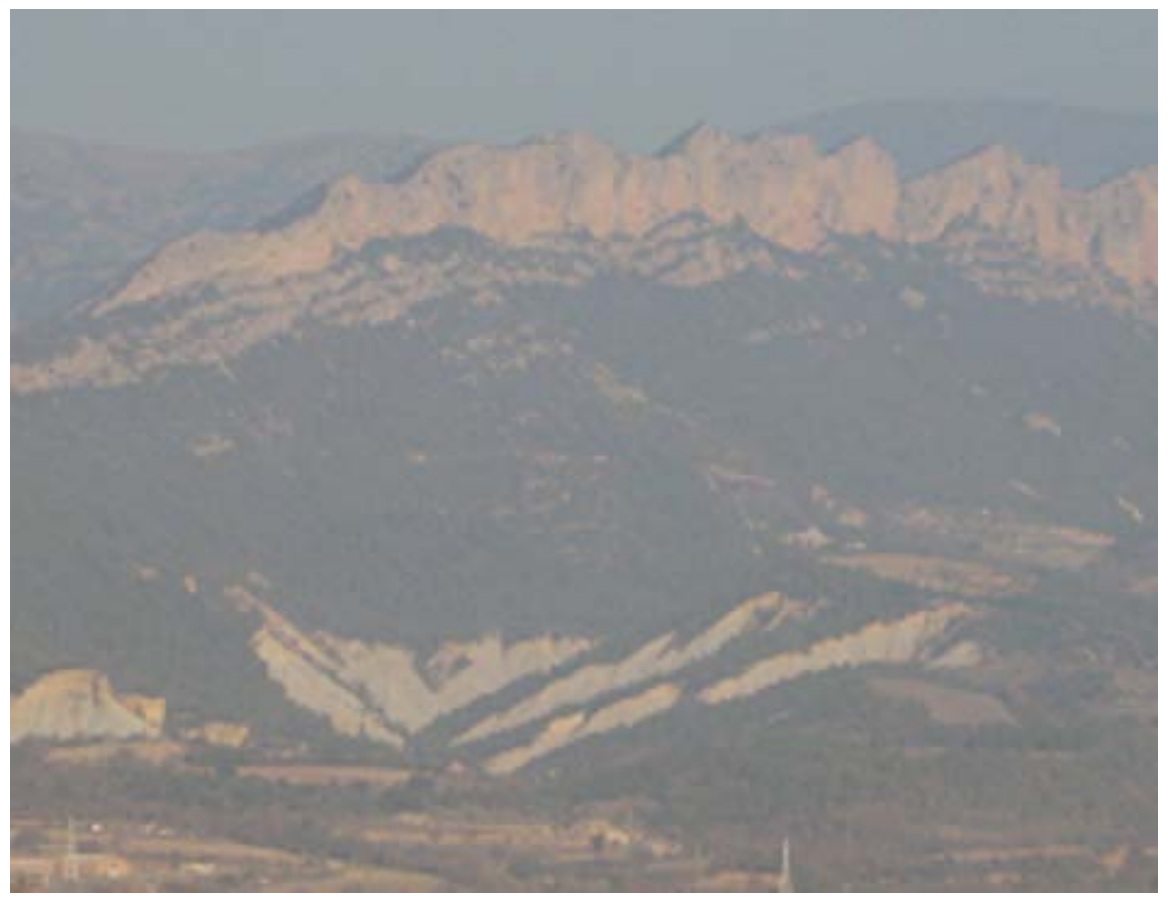

FOTOGRAFIA 9. PARADA 8

Anticlinal d'Oliana, des de dels Terrers de Peramola. Afloraments de calcolutites grises de l'Eocè, encavalcades per calcàries cretàciques del Mantell del Montsec (Serra de Turb).

\subsection{Parada 9. GRAVERES D'OLIANA, (terme municipal d'Oliana, comarca de I'Alt Urgell). (Full 291).}

Després de fer la parada anterior, cal acabar d'arribar fins a Peramola. Després caldrà anar cap a Oliana. En passar a l'altra banda del riu, caldrà fer una nova aturada, si s'escau. A uns 4 $\mathrm{Km}$ de l'anterior.

En aquest recorregut hem anat circulant per entre els materials terciaris que pertanyen a la Depressió Geològica de I'Ebre (em concret a la denominada la Zona de l'Avant-país Plegat), tot i que sovint es troben recoberts per terrenys detrítics quaternaris. Precisament, ara ens trobem en aquesta unitat geològica.

En aquest indret ens trobem a la vora del riu Segre, on hi havia una explotació d'àrids, extrets de la terrassa baixa de l'esmentat riu. A l'actualitat aquesta explotació es troba totalment aturada. FOTOGRAFIA 10. 


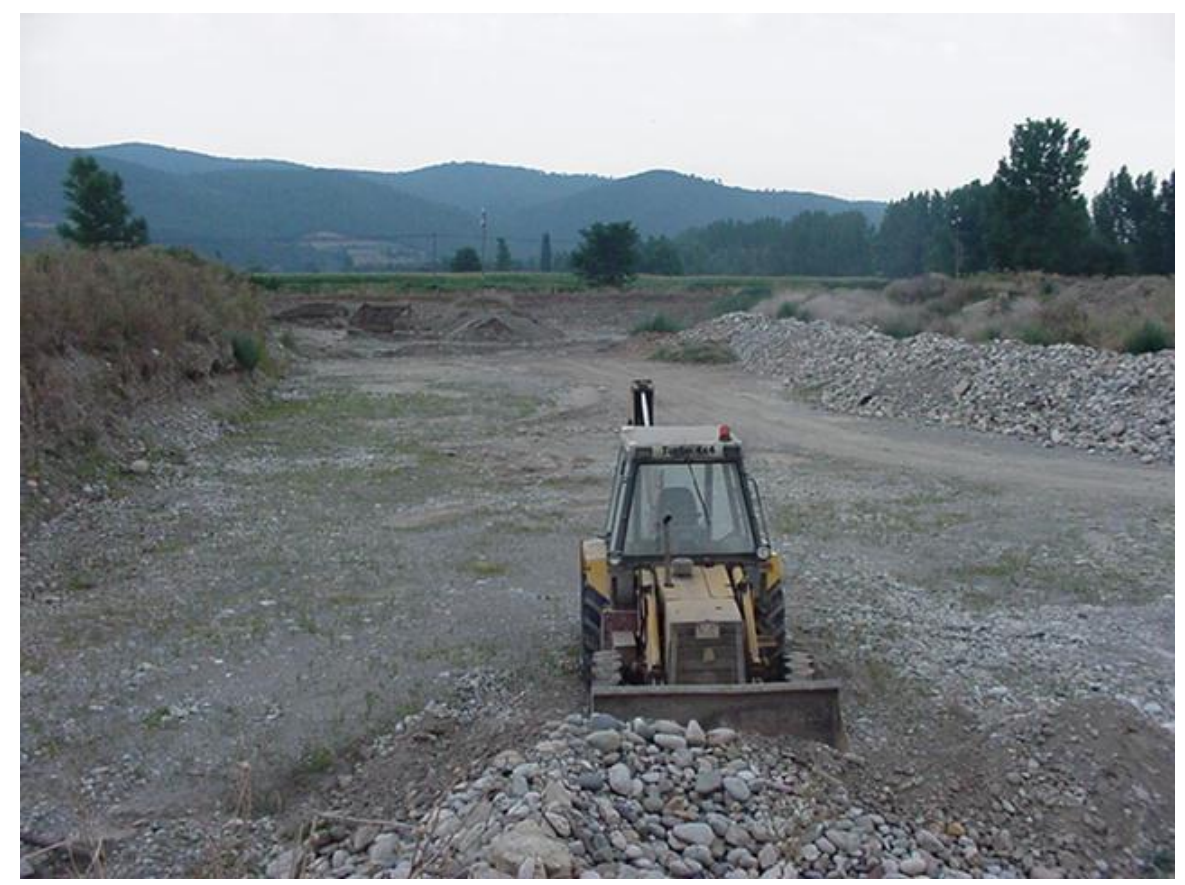

FOTOGRAFIA 10. PARADA 9.

Un aspecte de la gravera d'Oliana

\subsection{Parada 10. BARRANC DE VALLDAN (termes municipals d'Oliana i d'Odén, comarques de l'Alt Urgell i del Solsonès, subcomarca de l’Urgell Mitjà). (Full 291).}

Després de fer l'aturada anterior, cal acabar d'arribar a la població d'Oliana. Aquí cal agafar la carretera C-1313, per tal d'anar cap al Nord. Però a la sortida d'Oliana caldrà agafar la carretera que es dirigeix cap a la Valldan (i que parteix de l'antiga carretera C-1313, actual C 14), fins arribar a uns $2 \mathrm{Km}$ del seu inici, a mig camí del darrer poble. Aquí farem una nova aturada, a uns $4 \mathrm{Km}$ de l'anterior.

Des d'aquest indret es pot gaudir d'un bon lloc d'observació de I'Anticlinal d'Oliana, el qual presenta una direcció NE-SW. Aquest anticlinal es situa sobre els materials eocènics superiors de la Depressió Geològica de l'Ebre, al peu de I'Encavalcament principal sud-pirinenc. Aquest anticlinal s'inclou dintre de I Avant-país plegat.

Els materials eocènics es troben constituïts per nivells de calcolutites grisenques, i pertanyen a la Formació Igualada.

En aquest indret finalitza el recorregut de l'itinerari 


\section{Bibliografia}

GUIMERÀ, J. et altri (1992).- Geologia (II), Història Natural dels Països Catalans, Vol.2, 547 pag. Enciclopèdia Catalana, S.A. Barcelona

IGME (1970).- Mapa Geológico de España, a escala 1.200.000 (Síntesis de la Cartografia existente). Full i memòria $n^{\circ}$ 24, Berga. Inst. Geol. Minero de España. Madrid

IGME (1994).- Mapa Geológico de España a escala 1:50.000 (Plan Magna). Fulla i Memòria $n^{\circ}$ 252 (Tremp). Inst. GeoMinero y Tecnol. España. Minist. Indústria. Madrid

MATA - PERELLÓ, J.M. (1991).- Els Minerals de Catalunya. Arxius de la Secció de Ciències, t. XCIII, 442 pag. Institut d’Estudis Catalans. Barcelona

MATA-PERELLÓ, J.M. (2002a).- Recerca geològica i mineralògica per la comarca del Pallars Jussà: des del Port de Comiols a Llimiana i a Tremp. Revista Xaragall, sèrie B, nº 194, 8 pag. Manresa

MATA-PERELLÓ, J.M. (2002b).- Recorregut de recerca geològica i mineralògica per la comarca del Pallars Jussà: des del Port de Comiols a Tremp i a Xerallo. Inèdit. 11 pàgines. Manresa

MATA-PERELLÓ, J.M. (2005).- Recorregut de recerca geològica i mineralògica per les comarques de la Noguera i de I'Alt Urgell (per la subcomarca de I'Urgell Mitjà): des de Ponts a Folquer, a Peramola, Oliana i a la Palanca de Noves. Inèdit. 10 pàgines. Manresa

MATA-PERELLÓ, J.M. (2006).- Recorregut de recerca geològica i mineralògica per les terres de la Noguera i de l'Alt Urgell: des de Gualter a la Serra, Bellfort, Sant Marc, Peramola i Oliana. Inèdit. 10 pàgines. Manresa

MATA-PERELLÓ, J.M. (2009).- Recorregut de recerca geològica i mineralògica per la comarca del Pallars Jussà: des de la Pobla de Segur a Tremp i a Isona, tot passant per Basturs, Suterranya i Abella. Inèdit. 8 pàgines. Manresa

MATA-PERELLÓ, J.M. (2013).- Recorregut de recerca geològica i mineralògica per la comarca del Pallars Jussà: des d'Erinyà a la Pobla de Segur, a Tremp i a Isona, tot passant per Figuerola d'Orcau, Basturs i Abella de la Conca. Inèdit. 12 pàgines. Manresa

MATA-PERELLÓ, J.M. i MONTANÉ GARCÍA, P. (2005).- Recorregut de recerca geològica i mineralògica per la comarca del Pallars Jussà: des de la pobla de Segur a Tremp i a Isona, tot passant per les immediacions de Basturs, de Suterranya i de Bóixols. Inèdit. 8 pag, Manresa

MATA-PERELLÓ, J.M. i MONTANÉ GARCÍA, P. (2006).- Recorregut de recerca geològica i mineralògica per la comarca del Pallars Jussà: des de la Pobla de Segur i les Mines de Sossís cap a Tremp i a Isona, tot passant per Basturs, Suterranya, Abella i la Posa. Inèdit. 10pag. Manresa

MATA-PERELLÓ, J.M. i SANZ BALAGUÉ, Q. (2014).- Recorregut de recerca geològica i mineralògica per I comarca del Pallars Jussà: des de la Pobla de Segur, a Tremp i a Isona, tot passant per Talarn, Figuerola d'Orcau, Basturs i Abella de la Conca. Inèdit.12 pàgines. Manresa

RIBA, O. et altri (1976).- Geografia Física dels Països Catalans, Edit. Ketres, 254 pàgines. Barcelona. 